\title{
Effect of initial state and processing temperature on structure and properties under hot torsion of AA5754 alloy
}

\author{
A. Kulakowska ${ }^{1}$, K. Laber ${ }^{2}$, H. Dyja ${ }^{3}$, A. Zavdoveev ${ }^{\dagger, 4}$ \\ †avzavdoveev@gmail.com \\ ${ }^{1}$ Jan Dlugosz University in Czestochowa, Faculty of Science and Technology, Czestochowa, 42-200, Poland \\ ${ }^{2}$ Czestochowa University of Technology, Faculty of Production Engineering and Materials Technology, \\ Czestochowa, 42-200, Poland \\ ${ }^{3}$ Metal Forming Institute, Poznan, 61-139, Poland \\ ${ }^{4}$ The Paton Electric Welding Institute NAS of Ukraine, Kyiv, 03150, Ukraine
}

The effect of initial state and processing temperature of AA5754 alloy during hot torsion tests is presented. This deformation scheme allows simulating complex strain-stressed conditions. The tests were conducted on specimens solution heat treated in water and for specimens after extrusion and homogenizing treatment, respectively. It was determined that in the investigated range of deformation parameters, the solution treatment process has no effect on the plasticity of the alloy under investigation, but does have an influence on its hardness, microhardness distribution and grain size. In particular, the specimens deformed in the initial state behave according to the deformation pattern i.e. the maximum values of hardening and grain refinement occur on the deformed specimen surface, while the minimum values, inside the specimen. The same effect of deformation was observed for solution-treated specimens deformed at $250^{\circ} \mathrm{C}$. While deformation in the extruded and homogenized state, the most uniform hardness distribution and the maximum deformation were exhibited by specimens deformed at $250^{\circ} \mathrm{C}$. Thus, a successful attempt to incorporate knowledge obtained from severe plastic deformations (SPD) into the AA5XXX series aluminum alloys treatment has been made. The incorporation of SPD advantages allowed revealing age hardenable mechanism in non-age-hardenable alloy AA5XXX. All side investigation of structure and properties was made.

Keywords: torsion, aluminium alloy, solution treatment, microhardness distribution, structure.

УДК: 538.9

\section{Влияние исходного состояния и температуры обработки на структуру и свойства при горячем кручении сплава AA5754}

\author{
Кулаковская А. ${ }^{1}$, Лабер К. ${ }^{2}$, Дия Х. ${ }^{3}$, Завдовеев А. ${ }^{\dagger}, 4$ \\ ${ }^{1}$ Университет Яна Длугоша в Ченстохове, факультет науки и технологий, Ченстохова, 42-200, Польша \\ ${ }^{2}$ Ченстоховский технологический университет, факультет технологии производства и материалов, \\ Ченстохова, 42-200, Польша \\ ${ }^{3}$ Институт обработки металлов давлением, Познань, 61-139, Польша \\ ${ }^{4}$ Институт электросварки им. Е. О. Патона НАН Украины, Киев, 03150, Украина
}

Изучено влияние исходного состояния и температуры обработки сплава АА5754 на его поведение при испытаниях горячим кручением. Данная схема деформирования позволяет моделировать сложные деформационно-напряженные условия. Испытания проводились на образцах, термообработанных на твердый раствор в воде, и на образцах после экструзии и гомогенизирующей обработки, соответственно. Установлено, что в исследованном диапазоне параметров деформации процесс обработки на твердый раствор не влияет на пластичность исследуемого сплава, но влияет на его твердость, распределение микротвердости и размер зерна. В частности, деформированные в исходном состоянии образцы ведут себя в соответствии с характером деформации, т. е. максимальные значения упрочнения и измельчения зерна происходят на деформированной поверхности образца, а минимальные внутри образца. Такой же эффект деформации наблюдался для обработанных на твердый раствор образцов, деформированных при $250^{\circ} \mathrm{C}$. При деформации в экструдированном и гомогенизированном состоянии наиболее 
равномерное распределение твердости и максимальную деформацию показали образцы, деформированные при $250^{\circ} \mathrm{C}$. Таким образом, была предпринята успешная попытка применить знания, полученные в результате проведения интенсивных пластических деформаций (ИПД), для обработки алюминиевых сплавов серии АА5ХХХ. Использование преимуществ ИПД позволило выявить механизм упрочнения старением в неподверженном старению сплаве АA5XXX. Проведены всесторонние исследования структуры и свойств.

Ключевые слова: кручение, алюминиевый сплав, обработка раствором, распределение микротвердости, структура.

\section{Introduction}

Aluminium and aluminium alloys play a key role in contemporary engineering, as they are among the most commonly used non-ferrous materials. Owing to their high corrosion resistance, very good mechanical properties, good weldability and relatively low manufacture cost, aluminium alloys find wide application in the automotive, aircraft and other industries [1]. The permanent development of requirements for products from these alloys results in the search for opportunities to improve their properties through the applications of a variety of technological solutions. The most expanding method is Severe Plastic Deformation (SPD), which is alloy forming to obtain products with higher operating properties compared to conventional methods. Over the last twenty years, many methods of manufacturing these alloys on an industrial scale have emerged, the main objective of which is to produce a fine-grained microstructure (with a grain size below $1 \mu \mathrm{m}$ ), and even a nanometric structure (with a grain size below $100 \mathrm{~nm}$ ) in a material, well known as equal channel angular pressing (ECAP), high pressure torsion (HPT), twist extrusion (TE) and others [2-6]. The main purpose of these methods is to obtain a maximum fine (up to a nanometric scale) and regular microstructure. As is well-known, controlling the grain size is one of the major methods of regulating the mechanical properties of polycrystalline metallic materials [4].

Another way to influence the microstucture is heat treatment. For age-hardenable aluminium alloys, this treatment usually involves solution treatment and deformation at aging temperatures [7]. Despite the fact that alloys of the AA5XXX series are non-age-hardenable, according to a deformation study [8], this type of solution-treated aluminium alloys at temperatures between temperatures of intermetallic compounds separation and $200^{\circ} \mathrm{C}$ allows one to obtain a finegrained structure with high mechanical properties. However, the combination of heat treatment and plastic deformation has a greater influence on the properties of the materials [9]. As research results show [10-12], subsequent aging of Al-Mg alloys after Equal Channel Angular Pressing (ECAP) does not allow obtaining higher values of strength properties for non-age-hardenable aluminum alloys. However, there is no information on the influence of pre-annealing on the formability, microstructure and properties of $\mathrm{Al}-\mathrm{Mg}$ alloys.

Tests of magnesium alloy have shown a significant effect of the initial state on the microstructure and mechanical properties of this material and its formability [5,13-15]. The positive effect of deformation after heat-treatment on the microstructure and operational properties was shown for steel [16] and titanium [17].

The aim of the study was to verify whether the deformation of the Al-Mg alloy of Grade 5754, at a temperature of 200 and $250^{\circ} \mathrm{C}$ in a solution treated state will allow obtaining a structure finer than one obtained upon deforming this alloy after extrusion and homogenizing treatment. The torsion test was chosen as the deformation scheme for the study.

\section{Materials and methods}

The investigation covered by this article was carried out for the AA5754 aluminium alloy with a chemical composition that complies with EN 573-1 Standard. Some of the test specimens were solution treated at a temperature of $530^{\circ} \mathrm{C}$ for 30 minutes, followed by water cooling. At the first stage of testing, the specimens were subjected to dilatometric tests using a DIL805A/D dilatometer. The purpose of these tests was to determine the temperature of intermetallic compound precipitation from the solution treated alloy. The dilatometric tests showed that the precipitation of the intermetallic compounds of the tested material occurred at a temperature of about $175^{\circ} \mathrm{C}$.

The deformation process of the AA5754 alloy was conducted using an STD 812 torsion plastometer [18-20]. The investigation was carried out by restrained hot torsion tests considering the fact that this deformation mode induces a near-pure shear state in the material, refining the grain with severe plastic deformation, and enables the evaluation of the structure after the process. Solution treated specimens in the initial state (after extrusion and homogenizing treatment) were torsion tested at temperatures of 200 and $250^{\circ} \mathrm{C}$, respectively, until failure, using a deformation velocity of $0.1 \mathrm{~s}^{-1}$. Specimens with a working part length of $20 \mathrm{~mm}$ and a diameter of $8 \mathrm{~mm}$ were used for the tests. For temperature control, K-type (NiCr-Ni) thermocouples were employed.

For the computation of the actual deformation during the torsion, the plastometer control software used Eq. (1), whereas the actual deformation velocity was determined from relationship Eq. (2). The yield stress, on the other hand, was determined from Eq. (3) [21-22]:

$$
\begin{aligned}
& \varepsilon=\frac{2 \cdot \pi \cdot r \cdot N}{\sqrt{3} \cdot L}, \\
& \dot{\varepsilon}=\frac{2 \cdot \pi \cdot r \cdot \dot{N}}{\sqrt{3} \cdot 60 \cdot L}, \\
& \sigma_{p}=\frac{\sqrt{3} \cdot 3 M}{2 \pi r^{3}},
\end{aligned}
$$

where $r$ - specimen radius, $L-$ specimen length, $N-$ number of specimen torsions (rotations), $\dot{N}-$ torsion velocity (rotational speed), $M-$ torque.

The metallographic examinations were performed using a Nikon Eclipse MA-200 optical microscope. Hardness and microhardness tests were made on an FM-700 hardness tester 
and an FV-700 hardness tester supplied by FutureTech, using a load of $30 \mathrm{~N}$ and $5000 \mathrm{~N}$, respectively.

To identify the phases in the initial state (after extrusion and homogenization) and to verify the effectiveness of the heat (solution) treatment, an X-ray phase analysis was made on a SEIFFERT $3003 \mathrm{X}$-ray diffractometer using a cobalt tube with a wavelength of $\lambda=0.17902 \mathrm{~nm}$. During phase identification, the DHN PDS software program and crystallographic database was used.

\section{Results and discussion}

Fig. 1 shows the diffraction patterns of the investigated specimens of the AA5754 alloy in the initial state and after solution treatment, respectively.

As indicated by the data in Fig. 1, Al peaks are visible in the tested alloy both in its initial and solution treated states. The peaks coming from the $\mathrm{Al}_{2} \mathrm{Mg}_{3}$ and $\mathrm{Al}_{3} \mathrm{Mg}_{2}$ intermetallic compounds were observed only in the initial material, which suggests that the solution treatment parameters were selected correctly.

Fig. 2 shows flow curves for the investigated aluminium alloy as deformed at different temperatures, after extrusion and homogenization and after solution treatment.

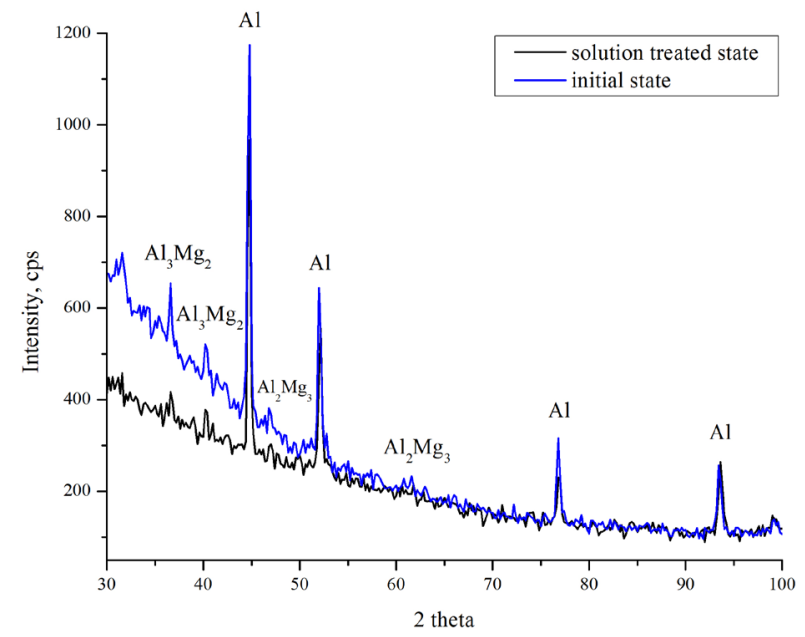

Fig. 1. (Color online) Diffraction patterns of specimens in the initial state and after solution treatment.

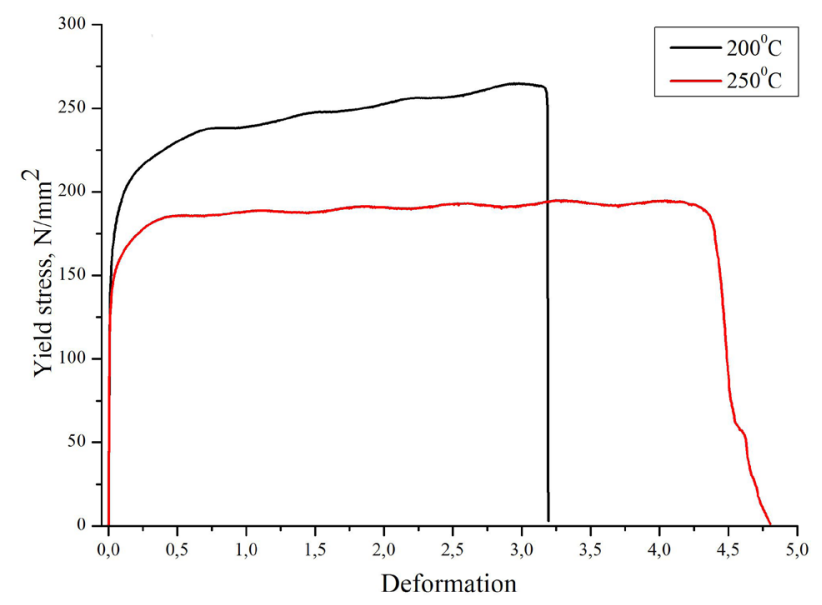

a
The analysis of the test alloy flow curves shows that, in the initial state during torsion at a temperature of $250^{\circ} \mathrm{C}$, the yield stress of the alloy was lower than the yield stress during deformation at $200^{\circ} \mathrm{C}$. The limiting deformation of the material tested at $250^{\circ} \mathrm{C}$ was almost 4.5. During torsion at $200^{\circ} \mathrm{C}$, the stress level in AA5754 alloy was higher by approx. $100 \mathrm{MPa}$ and the material lost its coherence already at a deformation of 3 . In the solution treated state, during torsion at $200^{\circ} \mathrm{C}$, the investigated alloy behaved in the same manner as it did in the initial stage. When deformed at $250^{\circ} \mathrm{C}$ in the solution treated state, the test material would fail at an actual deformation below 3 , in spite of the fact that it exhibited the lowest yield stress level. This could be associated with the fact that the precipitation of intermetallic phases occurred at that temperature, which was intensified by the deformation.

As can be seen from the data in Fig. 3, in the initial state, some inhomogeneity of hardness between the surface and the bulk of the specimen is observed. Upon solution treatment, this difference was minimal. The greatest surface hardening of test specimens deformed in the initial state was observed at a temperature of $200^{\circ} \mathrm{C}$. In the majority of the specimens, the hardness increased monotonically due to the deformation. The difference in hardness between the edge and center of the specimens after deformation at $250^{\circ} \mathrm{C}$ is minimal, amounting

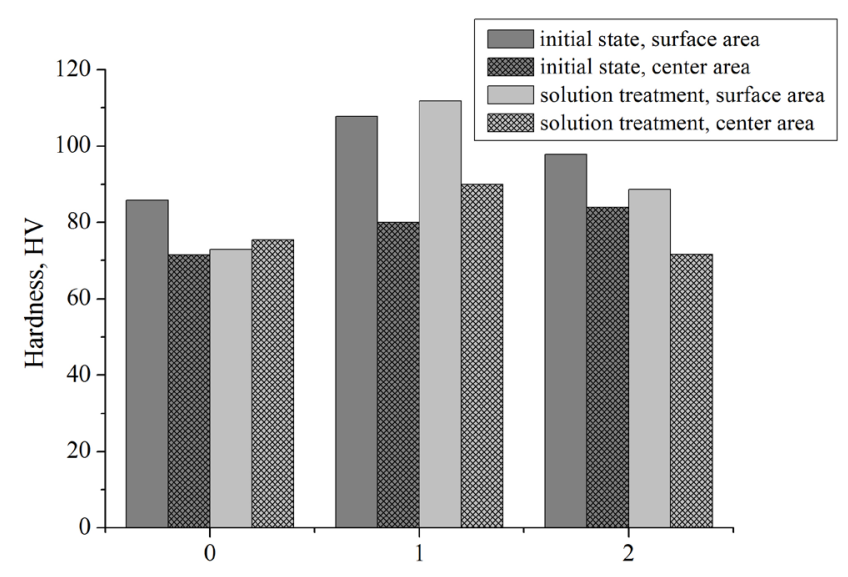

Fig. 3. The hardness of AA5754 alloy specimens: 0 - initial state; 1 - deformed at $200^{\circ} \mathrm{C} ; 2-$ deformed at $250^{\circ} \mathrm{C}$.

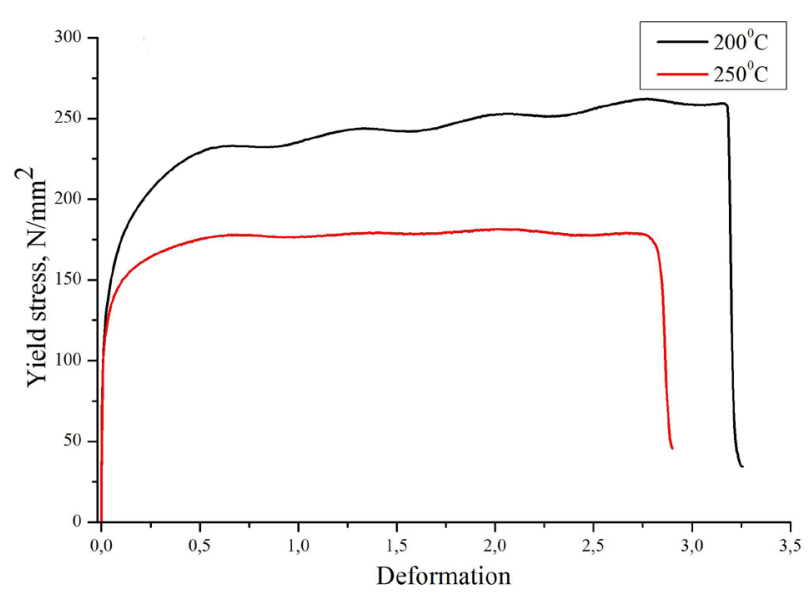

b

Fig. 2. (Color online) The flow curves for AA5754 aluminium alloy in the initial state (a), in the solution treated state (b), black line deformation temperature $200^{\circ} \mathrm{C}$, red line - deformation temperature $250^{\circ} \mathrm{C}$. 
to $15 \mathrm{HV}$. By contrast, in the solution treated state, the maximum hardening of both the surface and the bulk of the test AA5754 alloy specimens was observed after deformation at a temperature of $200^{\circ} \mathrm{C}$.

Fig. $4 \mathrm{a}$ and $4 \mathrm{~b}$ represent the distribution of microhardness in the cross-section and longitudinal sections of the AA5754 alloy specimens in the initial and solution treated states deformed at $200^{\circ} \mathrm{C}$ and $250^{\circ} \mathrm{C}$, respectively.

Analysis of the distribution of microhardness in the specimens of the investigated material in the initial state (Fig. 4 a) shows that the microhardness in the bulk of the specimen is lower than on the surface. This results from the nature of the torsion test, which is characterized by maximal deformation on the surface and minimal deformation in the bulk of the deformed specimen. After deformation at a temperature of $250^{\circ} \mathrm{C}$, the microhardness distribution curves were similar, except that the microhardness values in the longitudinal section were higher.

The distributions of microhardness in the cross-section and longitudinal section of specimens deformed in the solution treated state (Fig. 4 b) after deformation at $200^{\circ} \mathrm{C}$ and $250^{\circ} \mathrm{C}$ were similar. The distribution of the microhardness of the investigated alloy deformed at $200^{\circ} \mathrm{C}$ in the solution treated state differs from the microhardness distribution of the AA5754 alloy deformed in the initial state. The hardness distribution profile suggests that the deformation from one specimen side was greater than that from the other (the microhardness difference is approx. $7 \mu \mathrm{HV}$ ). The microhardness in the cross-section of the examined material was slightly lower than in the longitudinal section. The microhardness distribution profile of the examined material after deformation at $250^{\circ} \mathrm{C}$ is similar to that after deformation in the initial state (after extrusion and homogenization) i.e. the maximum microhardness values were observed on the specimen surface, while the minimal values - inside the specimen. The cause of that material behaviour might be the precipitates of intermetallic compounds at $250^{\circ} \mathrm{C}$, which resulted in the uneven microhardness distribution. The microhardness level of the AA5754 alloy after deformation at $250^{\circ} \mathrm{C}$ in the solution treated state was lower than that after deformation in the initial state.

Diffraction patterns for AA5754 alloy specimens after deformation at a temperature of $200^{\circ} \mathrm{C}$ and $250^{\circ} \mathrm{C}$, respectively, in a different state are shown in Fig. 5.

In the presented diffraction patterns (Fig. 5b), peaks from $\mathrm{Al}, \mathrm{Al}_{2} \mathrm{Mg}_{3}$ and $\mathrm{Al}_{3} \mathrm{Mg}_{2}$ are visible. After deformation in the solution treated state (Fig. $5 \mathrm{a}$ ), in addition to the $\mathrm{Al}$ peaks, there were additional peaks from the compounds

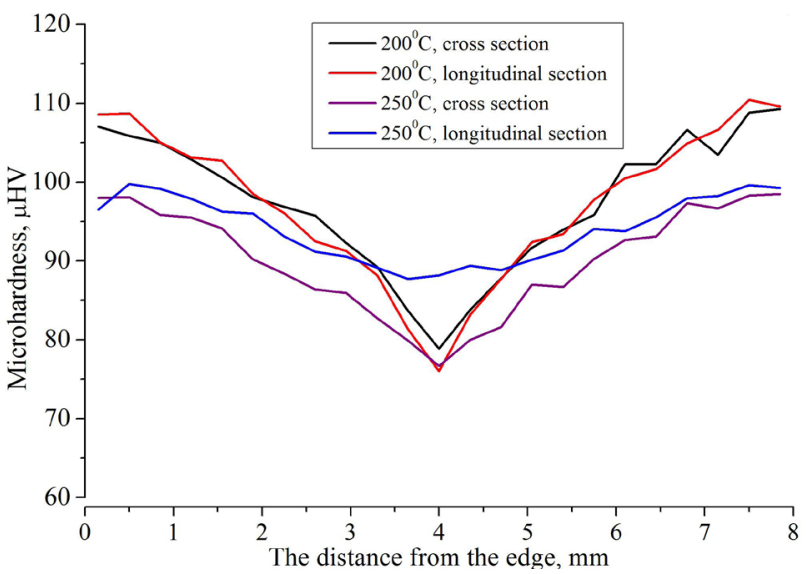

a

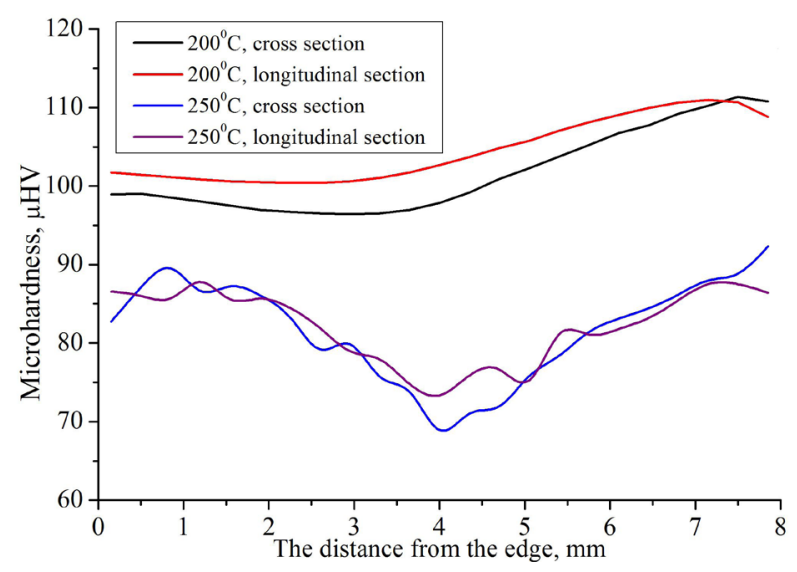

$\mathrm{b}$

Fig. 4. (Color online) The distribution of microhardness in the longitudinal section and cross-section of AA5754 alloy specimens after torsion in the initial state (a) and in the solution treated state (b).

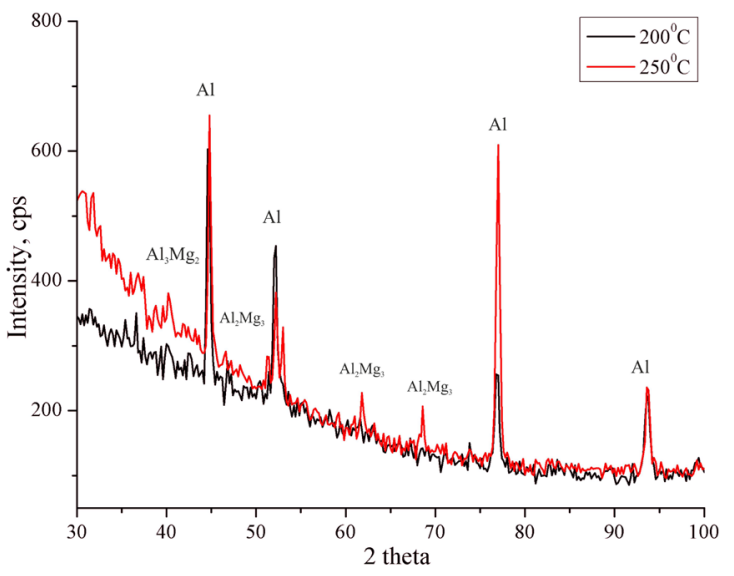

a

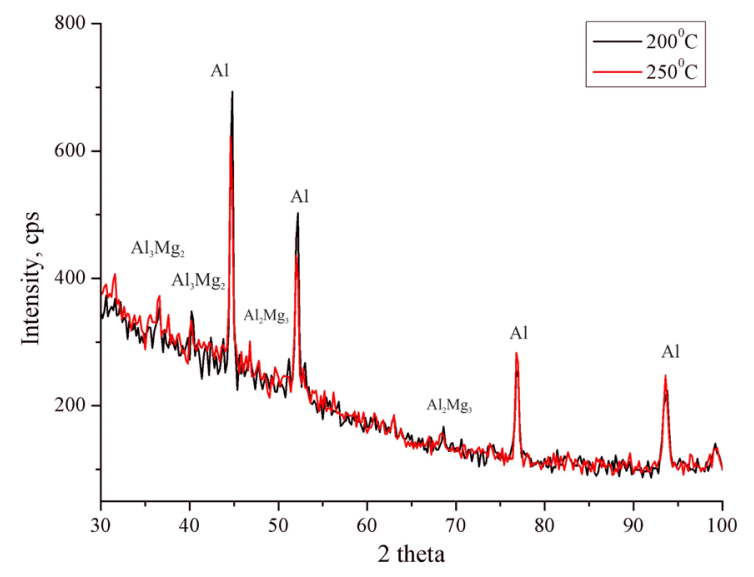

$\mathrm{b}$

Fig. 5. (Color online) The diffraction patterns of specimens after deformation at temperatures of 200 and $250^{\circ} \mathrm{C}$ in the solution treated state (a) and in the initial state (b). 
$\mathrm{Al}_{2} \mathrm{Mg}_{3}$ and $\mathrm{Al}_{3} \mathrm{Mg}_{2}$. This confirms that the decomposition of the supersaturated aluminium started in the material.

Measurements of the grain size in the initial state and in the solution treated state showed that in both cases the microstructure of the investigated alloy was homogeneous, both in the longitudinal section and in the cross-section. The grain size in the initial state was $85.62 \mu \mathrm{m}$. After solution treatment, a grain size growth to $93.98 \mu \mathrm{m}$ was observed.
After deformation at $200^{\circ} \mathrm{C}$, the grain size of the examined material was smaller than that after deformation at $250^{\circ} \mathrm{C}$, whereas as a result of torsion, the grains on the specimen surface were elongated (Fig. $6 \mathrm{~d}, \mathrm{~h}$ ) and had the smallest size. In the bulk of each specimen, where the deformation was negligible, the grains of the investigated alloy had a regular shape (Fig. 6a, c, e, g). In the cross-section and longitudinal section of the examined specimens, the grains had a regular

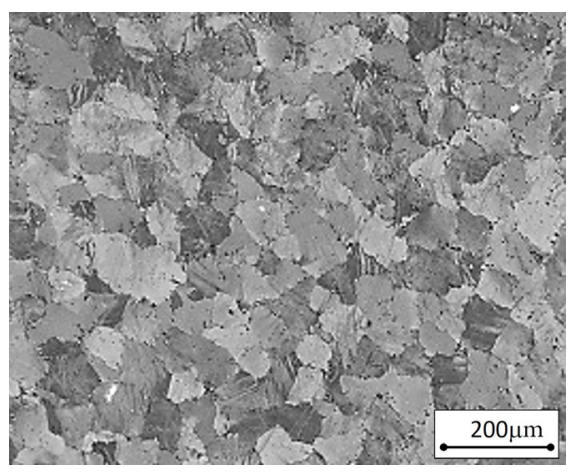

a

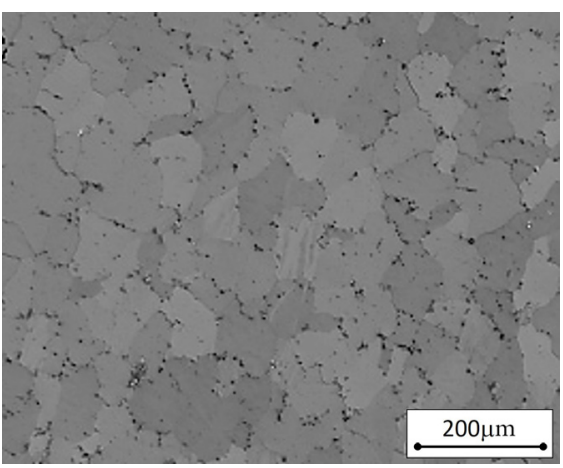

c

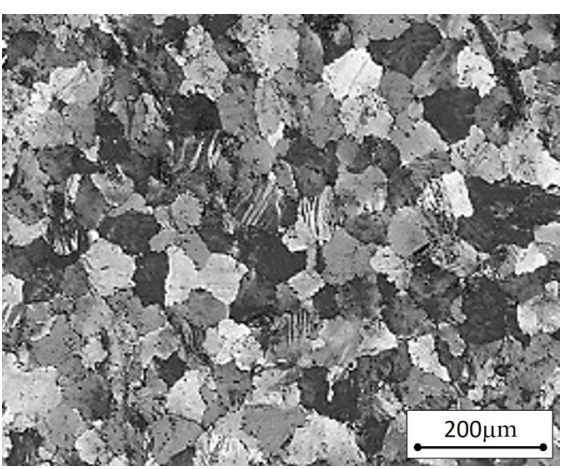

e

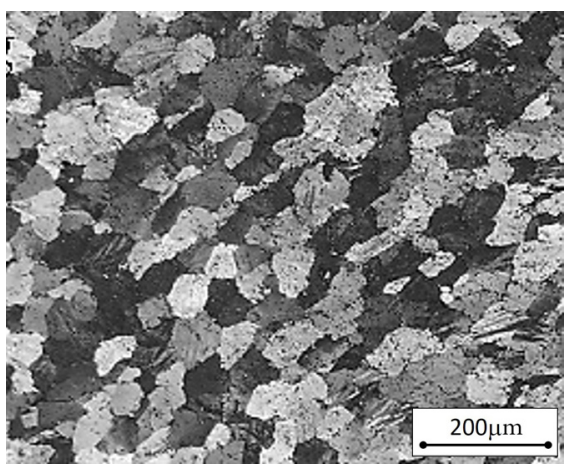

g

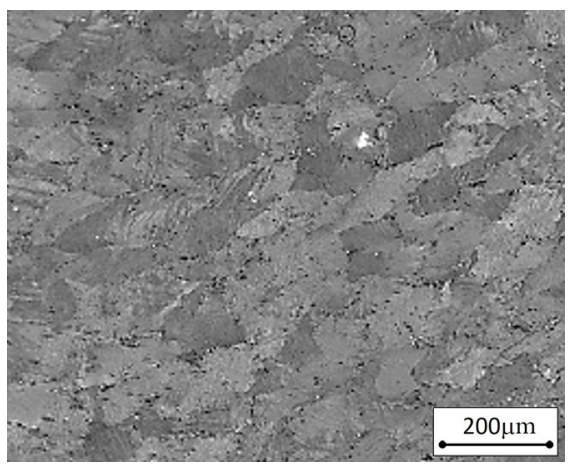

b

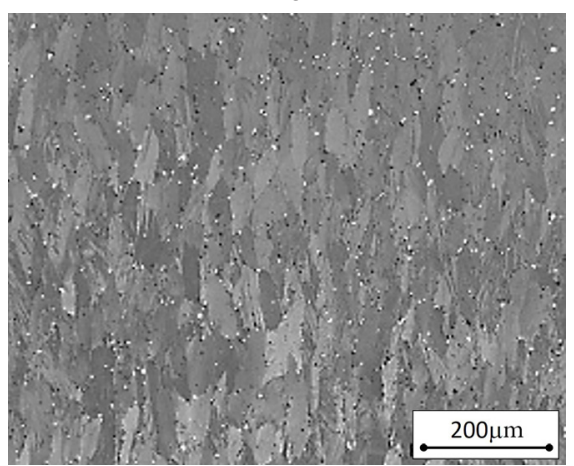

d

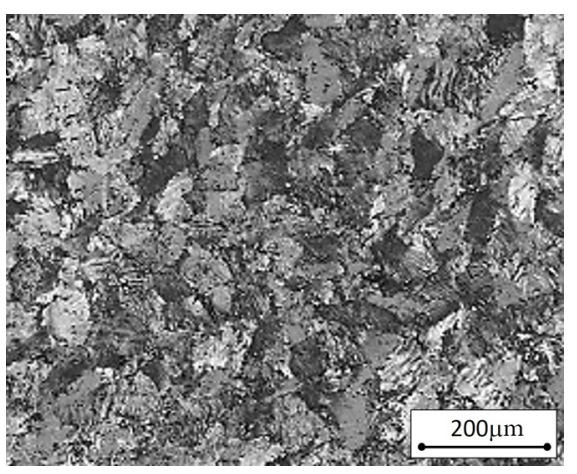

f

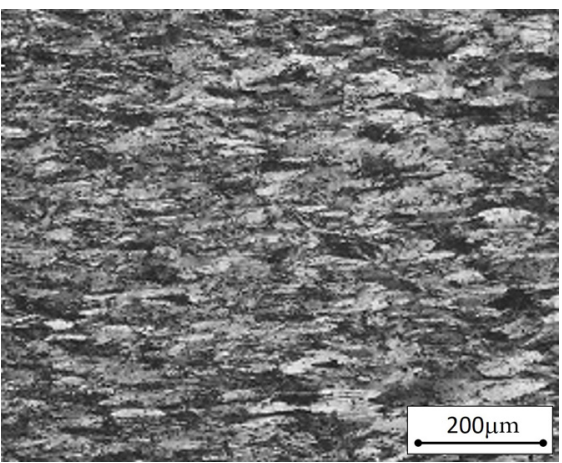

$\mathrm{h}$

Fig. 6. The microstructure of the specimens of the investigated aluminium alloy as deformed at $200^{\circ} \mathrm{C}$, for the specimens in the initial state (a-d), and in the solution-treated state (e-f): cross-section, specimen center (a, e); cross-section, specimen surface (b, f); longitudinal section, specimen center (c, g); longitudinal section, specimen surface (d, h). 
shape. After deformation of the AA5754 alloy at $250^{\circ} \mathrm{C}$, the relationships were similar, except for the specimen deformed in the solution treated state, where a significant grain growth was observed. In the case of the specimen deformed at $250^{\circ} \mathrm{C}$ in the initial state, greater grain refinement took place on the specimen surface, compared to the deformation at the lower temperature, although grain growth occurred inside the specimen.

\section{Conclusions}

Based on the investigation carried out and upon the analysis of the obtained results, it can be stated that:

- for the investigated AA5754 alloy, within the investigated range of parameters, the deformation of specimens in the solution treated state does not show any significant effect on the ductility of the material at a temperature of $200^{\circ} \mathrm{C}$, and at a temperature of $250^{\circ} \mathrm{C}$ even reduces it through the precipitation of intermetallic compounds;

- specimens deformed in the initial state (after extrusion and homogenization) behave according to the deformation pattern i.e. the maximum values of hardening and grain refinement occur on the deformed specimen surface, while the minimum values, inside the specimen. The same deformation effect was observed for solution treated specimens deformed at $250^{\circ} \mathrm{C}$;

- the deformation of the solution-treated specimens at $250^{\circ} \mathrm{C}$ resulted in the precipitation of intermetallic compounds (as confirmed by X-ray analysis) and in an appreciable grain growth;

- it was found that the deformation of the investigated alloy in the solution treated state adversely affected the deformation process, and the microstructure and hardness of the alloy;

- in the case of specimens deformed in the initial state, the most uniform hardness distribution and the maximum deformation were exhibited by specimens deformed at $250^{\circ} \mathrm{C}$.

\section{References}

1. I. Polmear, D. StJohn, J.-F. Nie, M. Qian, I. Polmear, D. StJohn, J.-F. Nie, M. Qian. Light Alloy. 2017, 157 (2017). Crossref

2. E. Pashinska, V. Varyukhin, S. Dobatkin, A. Zavdoveev. Emerg. Mater. Res. 2, 138 (2013). Crossref

3. H. S. Liu, B. Zhang, G. P. Zhang. J. Mater. Sci. Technol. 27, 15 (2011). Crossref

4. I. Sabirov, M. Y. Murashkin, R. Z. Valiev. Mater. Sci. Eng. A. 560, 1 (2013). Crossref
5. Z.C. Wang, P. B. Prangnell. Mater. Sci.Eng. A. 328, 87 (2002). Crossref

6. T. Mukai, M. Kawazoe, K. Higashi. Mater. Sci. Eng. A. 247, 270 (1998). Crossref

7. M. Knapinski, H. Dyja, A. Kawalek, T. Fraczek, K. Laber. Metalurgija. 52, 239 (2013).

8. J.A. Wert, N.E. Paton, C.H. Hamilton, M.W. Mahoney. Metall. Trans. A, Phys. Metall. Mater. Sci. 12 A, 1267 (1981). Crossref

9. N. T. Kareva, Y. D. Koryagin. Met. Sci. Heat Treat. 56, 483 (2015). Crossref

10. H. J. Roven, H. Nesboe, J. C. Werenskiold, T. Seibert. Mater. Sci. Eng. A. 410-411, 426 (2005). Crossref

11. T. Tański, P. Snopiński, W. Pakieła, W. Borek, K. Prusik, S. Rusz. Arch. Civ. Mech. Eng. 16, 325 (2016). Crossref

12. T. Tański, P. Snopiński, K. Prusik, M. Sroka. Mater. Charact. 133, 185 (2017). Crossref

13. T. Krajňák, P. Minárik, J. Stráská, J. Gubicza, K. Máthis, M. Janeček. J. Mater. Sci. 54, 3469 (2019). Crossref

14. K. Laber, A. Kułakowska, H. Dyja. METAL 2018-27th International Conference on Metallurgy and Materials, Conference Proceedings. Brno (2018) p. 1599.

15. T. Bajor, A. Kulakowska, H. Dyja. Materials. 13 (5), 1114 (2020). Crossref

16. Y. Xu, H. Jiao, Y. Zhang, F. Fang, X. Lu, Y. Wang, G. Cao, C. Li, R.D. K. Misra. J. Mater. Sci. Technol. 33, 1465 (2017). Crossref

17. J. Huang, K.-M. Zhang, Y.-F. Jia, C.-C. Zhang, X.-C. Zhang, X.-F. Ma, S.-T. Tu. J. Mater. Sci. Technol. 35, 409 (2019). Crossref

18. K. Laber. Hutnik-Wiadomości Hutnicze. 5, 238 (2015).

19. K. Laber, A. Kawałek, S. Sawicki, H. Dyja, J. Borowski, D. Leśniak, H. Jurczak. 2nd International Conference of Non-Ferrous Metals ICNFM'2015. Cracow, Poland, AGH University of Science and Technology (2015) p. 124.

20. S. Sawicki, A. Kawałek, K. Labek, H. Dyja, J. Borowski, D. Leśniak, H. Jurczak. 2nd International Conference on Non-Ferrous Metals ICNFM'2015. Cracow, Poland, AGH University of Science and Technology (2015) p. 129.

21. H. Dyja, A. Gałkin, M. Knapiński. Reologia metali odkształcanych plastycznie. Czestochowa, University Press of the Czestochowa University of Technology (2010) $220 \mathrm{p}$.

22. F. Grossman, E. Hadasik. Technologiczna plastyczność metali. Badania plastometryczne. Katowice, University Press of the Silesian University of Technology (2005) pp. 11-12. 